\title{
Breaking apple dormancy using thidiazuron and air temperature effect on herbicide efficiency for ryegrass control
}

\author{
Leonardo Bianco de Carvalho
}

Thidiazuron can be used to promote sprouting induction in apples, found DE MARTIN et al. (2017). Authors concluded that the application of thidiazuron on 'Daiane' apples with a concentration of 125 and 250 $\mathrm{mg} \mathrm{L}^{-1}$, added to mineral oil $(3.5 \%)$, is a viable alternative to break gem dormancy with no negative impact on fruit production. The use of chemicals to break gem dormancy in apples is important if winter temperatures are not sufficiently low for dormancy overlapping (FRANCESCATTO 2014). The most common chemical used is hydrogen cyanamide, but it can be toxic for humans, especially for the applicators (HAWERROTH et al. 2010). Thus, this study reveals a less toxic alternative to break gem dormancy in 'Daiane' apples, guaranteeing similar production to the most commonly used chemical.

The air temperature at the moment of herbicide spraying affects the efficiency of the chemical control of Italian ryegrass, found PEREIRA et al. (2017). Authors concluded that many grass killers are more efficient if application occurs at $20-22{ }^{\circ} \mathrm{C}$. In addition, applications under temperatures of $30-34{ }^{\circ} \mathrm{C}$ are negatively affected, reducing the chemical control of ryegrass; moreover, the response can also be different among biotypes. Herbicide effect depends on many factors, including plant physiology, environmental conditions, application conditions etc., and those factors also influence each other (CARVALHO 2013). Air temperature (an environmental condition) can affect, for example, both plant physiology and herbicide properties. As herbicide absorption (also translocation and metabolism) is fundamental to herbicide action in plants, any factor affecting the movement of a plant killer into plant cells influences the chemical toxic action. Thus, the interaction among those factors is difficult to measure, so that any information on isolated effects is fundamental to establish efficient weed control programs.

\section{REFERENCES}

CARVALHO LB. 2013. Herbicidas. Lages: Ed. Autor. 62p.

DE MARTIN MS et al. 2017. Quebra da dormência de macieiras 'Daiane' pelo uso do tidiazurom. Revista de Ciências Agroveterinárias 16: 81-87.

FRANCESCATTO P. 2014. Desenvolvimento das estruturas reprodutivas da macieira (Malus domestica Borkh) sob diferentes condições climáticas: da formação da gema à colheita dos frutos. Tese (Doutorado em Recursos Genéticos Vegetais). Florianópolis: UFSC. 293p.

HAWERROTH FJ et al. 2010. Cianamida hidrogenada, óleos mineral e vegetal na brotação de gemas e produção de macieiras 'Royal Gala'. Semina: Ciências Agrárias 31: 1145-1154.

PEREIRA LV et al. 2017. A eficácia do controle químico varia com o genótipo de azevém e a temperatura do ar no momento da aplicação. Revista de Ciências Agroveterinárias 16: 102-108.

Universidade Estadual Paulista, Jaboticabal, SP, Brasil.

* Author for correspondence <lbcarvalho@fcav.unesp.br> 